\title{
The Alpha2-Adrenergic Receptor Gene and Body Fat Content and Distribution: The HERITAGE Family Study
}

\author{
Christophe Garenc, ${ }^{1}$ Louis Pérusse, ${ }^{1}$ Yvon C. Chagnon, ${ }^{2}$ Tuomo Rankinen, ${ }^{3}$ Jacques Gagnon, ${ }^{4}$ \\ Ingrid B. Borecki, ${ }^{5}$ Arthur S. Leon, ${ }^{6}$ James S. Skinner, $^{7}$ Jack H. Wilmore, ${ }^{8}$ D. C. Rao, ${ }^{5,9}$ \\ and Claude Bouchard ${ }^{3}$ \\ ${ }^{1}$ Division of Kinesiology, Department of Preventive Medicine, Laval University, Ste-Foy, Québec \\ ${ }^{2}$ Laval University Research Center Robert-Giffard, Laval University, Ste-Foy, Québec \\ ${ }^{3}$ Pennington Biomedical Research Center, Louisiana State University, Baton Rouge, Louisiana, USA \\ ${ }^{4}$ Laboratory of Molecular Endocrinology, CHUQ Research Center, CHUL Pavilion, Ste-Foy, Québec \\ ${ }^{5}$ Division of Biostatistics, Washington University Medical School, St. Louis, Missouri, USA \\ ${ }^{6}$ School of Kinesiology and Leisure Studies, University of Minnesota, Minneapolis, Minnesota, USA \\ ${ }^{7}$ Department of Kinesiology, Indiana University, Bloomington, Indiana, USA \\ ${ }^{8}$ Department of Health and Kinesiology, Texas A\&M University, College Station, Texas, USA \\ ${ }^{9}$ Department of Genetics and Psychiatry, Washington University Medical School, St. Louis, Missouri, USA
}

Accepted February 7, 2002

\begin{abstract}
Background: Among adrenergic receptor subtypes that regulate lipid mobilization, the $\alpha 2$-adrenergic receptor is involved in the inhibition of fatty acid mobilization from adipose tissue. A C-1291G polymorphism is located in the $\alpha 2$-adrenergic receptor gene (ADRA2A) but no association with body fat accumulation has been reported yet.

Materials and Methods: Body mass index (BMI), fat mass (FAT), percentage body fat (\%FAT), trunk-to-extremity skinfold ratio (TER), sum of eight skinfolds (SF8), and abdominal subcutaneous (ASF), visceral (AVF), and total (ATF) fat areas assessed by CT scan have been measured in adult sedentary white $(n=503)$ and black $(n=276)$ subjects participating in the HERITAGE Family Study. Association between the C-1291G polymorphism and each phenotype was tested separately in men and women of
\end{abstract}

each race using ANCOVA with the effects of age as covariate in addition to the effects of BMI for TER and of FAT for AVF, ASF, and ATF.

Results: The allele frequencies of the ADRA2A C-1291G polymorphism differed between races. No association was observed in white subjects, except for a moderate effect of the polymorphism accounting for less than $1 \%$ of the variance in AVF and ATF in women. In black subjects, however, the G-1291 allele was found to be associated with an increase of TER in men $(3.8 \%$ of variance accounted for by the polymorphism), while in black women it was associated with a decrease in TER (2.9\%) and in AVF $(2.5 \%)$.

Conclusion: These results suggest a role for the ADRA2A gene in determining the propensity to store fat in the abdominal area, independently of total body fatness.

\section{Introduction}

Adrenergic receptor subtypes are involved in the regulation of lipid mobilization. In human adipose tissue, the $\beta 1-, \beta 2-$, and $\beta 3$-adrenergic receptors stimulate lipolysis while the $\alpha 2$-adrenergic receptor inhibits lipolysis through G-proteins (1). It has been suggested that the net lipid mobilization depends on the balance between the stimulatory and the inhibitory effects of catecholamines on $\beta$ - and $\alpha 2$ adrenergic receptors, respectively $(2,3)$.

Functional studies have shown that the net catecholamine effect on a specific adrenergic receptor

Address correspondence and reprint requests to: Louis Pérusse, $\mathrm{PhD}$, Division of Kinesiology, Department of Preventive Medicine, PEPS -Laval University, Ste-Foy, Québec GIK 7P4, Canada. Phone: (418) 656-7831; fax: (418) 656-3044;

e-mail: louis.perusse@kin.msp.ulaval.ca. subtype is not homogeneous across depots of adipose tissue, is different in men and women, and is affected by the level of obesity. The number of $\alpha 2$ sites is higher than the number of $\beta$ sites in the femoral and abdominal subcutaneous fat depots, but equal in the abdominal visceral fat depots $(3,4)$. Compared to lean subjects, obese men are characterized by a stronger $\alpha 2$-adrenergic component in the abdominal subcutaneous fat depot; no difference is observed in the femoral depot. However, in obese women, the $\alpha 2$-adrenergic component is more important in the subcutaneous abdominal and femoral depots $(5,6)$. An $\alpha 2$-adrenergic antilypolytic effect can partly explain the difference between the gynoid and the android pattern of fat distribution observed on average in women and men, respectively (7). The balance between the $\beta$ - and the $\alpha 2$ adrenergic receptor components could potentially 
explain the high catecholamine-induced lipolysis observed in visceral fat depot as compared to the abdominal subcutaneous fat depot $(8,9)$. In addition, several studies showed that the $\alpha 2$-adrenoceptor component behaves differently in response to exercise according to the level of obesity. Using microdialysis probes in subcutaneous abdominal fat cells of men, the $\alpha 2$-adrenergic component has been shown to impair lipid mobilization during exercise through activation of $\alpha 2$-adrenergic receptors by epinephrine (10) in a greater extent in obese than in normal-weight subjects (11). This effect was observed despite the high catecholamine concentration observed during exercise that was proposed to preferentially stimulate the $\beta$-adrenergic component (3). These observations and the evidence suggesting that total adiposity, fat distribution, and visceral fat are influenced by genetic factors (12-14), support the role of the $\alpha 2$-adrenoceptor gene (ADRA2A) as a candidate gene for adiposity and fat distribution.

The ADRA2A, which maps to chromosome $10 \mathrm{q} 25$, is expressed in subcutaneous and visceral fat depots (15). Several DNA polymorphisms have been detected in the ADRA2A gene, including the Dra I restriction fragment length polymorphism (RFLP) (16) that was tested for association with essential hypertension $(17)$ and fat distribution $(18,19)$ in the Québec Family Study. In the Québec Family Study, the Dra I RFLP was associated with the trunkto-extremity skinfolds ratio measurement in females, suggesting that this polymorphism favors the accumulation of fat in the truncal-abdominal region. Recently, this polymorphism was shown to be associated with abdominal subcutaneous fat areas (19). Another polymorphism of the ADRA2A gene, a C to G transversion in the promoter region (position -1291) was detected by Lario et al. (20) but, to the best of our knowledge, no association or linkage studies between the latter polymorphism and obesityrelated phenotypes have been reported yet.

In the present study, we investigated the associations between the C-1291G polymorphism located in the promoter region of the ADRA2A gene and total adiposity and fat distribution measured in subjects from the HERITAGE Family Study.

\section{Methods}

Subjects

The sample of the present study includes a total of 503 (245 men and 258 women) white and 276 (91 men and 185 women) black adult subjects, who are participants in the HERITAGE Family Study. In the present study, we used only the baseline HERITAGE data. All subjects had to be sedentary, in good health, and meet a set of inclusion criteria described in detail elsewhere (21). The Institutional Review Board of each university of the HERITAGE Family Study research consortium approved the study protocol. Written informed consent was obtained from each participant.

\section{Phenotype Measurements}

Anthropometric and Body Density Measurements These measurements have been described in detail previously (22). Body mass index (BMI) was calculated as weight $(\mathrm{kg}) /$ height $^{2}\left(\mathrm{~m}^{2}\right)$. The trunk-to-extremity skinfolds ratio $($ TER $=[$ subscapular + suprailiac + abdominal + midaxillary]/[biceps + triceps + medial calf + thigh]) was used as an indicator of the propensity to store fat in the truncal-abdominal area relative to the extremities. The sum of eight skinfolds (SF8) was used to assess the level of subcutaneous fat. Hydrostatic weighing was used to assess body density. Percentage body fat (\%FAT) was estimated from body density and fat mass (FAT) was derived (22).

Abdominal Visceral, Subcutaneous, and Total Fat Areas Abdominal fat was assessed by computed tomography (CT) as previously described (14). Scans were obtained between the fourth and fifth lumbar (L4-L5) vertebrae, with subjects in the supine position with arms stretched above the head. Total fat area was calculated using an attenuation range of -190 to -30 Hounsfield units. Abdominal visceral fat (AVF) area was defined by drawing a line within the inner portion of the muscle walls surrounding the abdominal cavity. Abdominal subcutaneous fat area (ASF) was obtained by calculating the difference between abdominal total fat (ATF) and AVF areas.

\section{Genotype Determination}

PCR Amplification of the C-1291G Polymorphism DNA was extracted from lymphoblastoid cell lines after digestion by proteinase $\mathrm{K}$ and purification with phenol-chloroform (23). PCR amplification was carried out in a volume of $20 \mu \mathrm{l}$ containing $150 \mathrm{ng}$ DNA; $200 \mu \mathrm{M}$ of each dATP, dCTP, dGTP, and dTTP; $1 \times$ buffer $(50 \mathrm{mM} \mathrm{NaCl}, 10 \mathrm{mM}$ Tris- $\mathrm{HCl}, 10 \mathrm{mM}$ $\mathrm{MgCl}_{2}, 1 \mathrm{mM}$ DTT, $\mathrm{pH}=7.5$ at $25^{\circ} \mathrm{C}$ ); $2 \times$ of Q solution; $50 \mathrm{nM}$ of each primer; and $1 \mathrm{U}$ of Taq polymerase (Perkin Elmer Cetus, Shelton, CT). The forward primer was 5'-TCACACCGGAGGTTACTTCCCTCG-3' and the reverse primer was 5'-TCCGACGACAGCGCGAGTT-3'. These primers generated a product of $522 \mathrm{bp}$ that was cut into five fragments $(5,62,116,165$, and $174 \mathrm{bp})$ with the Msp I restriction enzyme. The 174-bp fragment was cut into two bands (121 and $53 \mathrm{bp}$ ) in the presence of the G-1291 allele (20). The amplification protocol was 1) one cycle of denaturation at $94^{\circ} \mathrm{C}$ for $3 \mathrm{~min}$, annealing at $63^{\circ} \mathrm{C}$ for $1 \mathrm{~min}$, and extension at $72^{\circ} \mathrm{C}$ for $1 \mathrm{~min} ; 2$ ) 35 cycles of denaturation at $94^{\circ} \mathrm{C}$ for $30 \mathrm{sec}$, annealing at $63^{\circ} \mathrm{C}$ for $30 \mathrm{sec}$, and extension at $72^{\circ} \mathrm{C}$ for $45 \mathrm{sec}$; and 3) one final elongation cycle at $72^{\circ} \mathrm{C}$ for 10 min. A negative control without DNA was performed in every run of amplification.

After each amplification, PCR product was digested overnight at $37^{\circ} \mathrm{C}$ after adding $7.5 \mathrm{U}$ of the restriction enzyme Msp I to the PCR mixture. Resulting fragments were separated by electrophoresis 
in $2 \%$ agarose gels. Each gel was run for $2 \mathrm{hrs}$ at $150 \mathrm{~V}$, stained with ethidium bromide, and photographed under UV transmitted light. The $\Phi$ X174 DNA digested with Hae III was used as length marker to estimate the size of the digested DNA fragments. The allele without the Msp I restriction site is designated here as C-1291 allele (174 bp), whereas the allele with the Msp I restriction site is the G-1291 allele $(121+53 \mathrm{bp})$.

\section{Statistical Analysis}

All statistical analyses were performed using the SAS (24) software. A Chi-square test was performed to determine whether the genotype frequencies of the $\mathrm{C}$ 1291G ADRA2A polymorphism were in HardyWeinberg equilibrium, and to test for potential race differences in allele frequencies. We also calculated the polymorphic information content (PIC) (25).

Association Two genotype groups were considered: carriers (genotypes C-1291G and G-1291G) and noncarriers (genotype C-1291C) of the G-1291 allele. Because race and gender differences were previously reported for the body fat phenotypes investigated in the present study (26), associations between the C-1291G polymorphism and each phenotype were investigated separately in each of the four sex-by-race groups using an ANCOVA (general linear model) procedure that included the effects of age (age, age $\mathrm{e}^{2}$, and age $^{3}$ ) as covariables. AVF, ASF, and ATF were further adjusted for FAT. As previously done in the Québec Family study $(18,19)$, and for comparison purpose, TER was also adjusted for BMI to control for the level of adiposity.

\section{Results}

Allele and genotype frequencies of the ADRA2A C$1291 \mathrm{G}$ polymorphism are presented in Table 1 . The allele frequencies are strikingly different between white and black subjects, with blacks exhibiting a greater frequency of the G-1291 allele (0.66) compared to whites $(0.27)$. However, allele frequencies of whites did not differ from those reported in other healthy (C-1291 allele: 0.71) or hypertensive (C-1291 allele: 0.77) white subjects (20).

The results of the association analyses between the C-1291G polymorphism in the ADRA2A gene and obesity-related phenotypes are presented in Table 2 for whites and Table 3 for blacks. No significant evidence of association was observed in white men. The G-1291 allele was associated with lower $\operatorname{AVF}(-11.4 \% ; p=0.02)$ and ATF $(-4 \% ; p=0.03)$ in white women and a greater TER $(26.6 \% ; p=0.04)$ and ASF $(14.4 \% ; p=0.03)$ in black men. However, the low percentage of variance accounted for by the C-1291G polymorphism for AVF (0.74\%) and ATF $(0.18 \%)$ in white women and for ASF $(0.37 \%)$ in black men suggests that these associations have little biological significance. The strongest results were observed in black women. The carriers of the G-1291 allele exhibited a lower TER $(-14.4 \% ; p=0.04)$ and AVF $(-27 \% ; p=0.002)$ than the noncarriers. The variance accounted for by the C-1291G polymorphism reaches $2.9 \%$ and $2.5 \%$ for TER and AVF, respectively. The association with TER was caused by a lower trunk skinfolds (carriers: $92 \pm 3 \mathrm{~mm}$; noncarriers: $101 \pm 10 \mathrm{~mm}$ ) and a higher extremity skinfolds (carriers: $94 \pm 3 \mathrm{~mm}$; noncarriers: $90 \pm 10 \mathrm{~mm}$ ) in carriers compared to noncarriers (data not shown). Black male carriers of the G-1291 allele exhibited a greater TER $(\mathrm{TER}=1.91 \pm 0.06)$ than noncarriers $(1.57 \pm 0.15$; $p=0.04$ ) (Table 3 ) and the percentage of variance accounted for by the C-1291G polymorphism was $3.8 \%$. The association with TER was caused by a greater trunk skinfolds (carriers: $80 \pm 4 \mathrm{~mm}$; noncarriers: $70 \pm 12 \mathrm{~mm}$ ) and a lower extremity skinfolds (carriers: $46 \pm 3 \mathrm{~mm}$; noncarriers: $56 \pm 8 \mathrm{~mm}$ ) in carriers compared to noncarriers (data not shown). AVF exhibited a significant association with the C-1291G polymorphism in black women. Because AVF was adjusted for total body fatness, the results support the hypothesis of a role of the ADRA2A C-1291G polymorphism in determining the amount of fat stored in the abdominal depot, independently of body fat mass.

Table 1. Genotype and allele frequencies of the $\alpha 2$-adrenergic receptor gene C-1291G polymorphism in sedentary white and black subjects of the HERITAGE Family Study

\begin{tabular}{|c|c|c|c|c|c|c|c|}
\hline & \multirow[b]{2}{*}{$n$} & \multirow[b]{2}{*}{ PIC } & \multicolumn{2}{|c|}{ Allele Frequency* } & \multicolumn{3}{|c|}{ Genotype Frequencies $^{\dagger}$} \\
\hline & & & C-1291 & G-1291 & C-1291C & C-1291G & G-1291G \\
\hline Whites & 494 & 0.32 & 0.73 & 0.27 & 0.53 & 0.40 & 0.07 \\
\hline Blacks & 274 & 0.35 & 0.34 & 0.66 & 0.09 & 0.50 & 0.41 \\
\hline
\end{tabular}

PIC, $n=$ number of subjects; polymorphism information content.

${ }^{*} \chi^{2}$ for race difference in allele frequencies $=111.8, \mathrm{df}=1, p<0.0001$.

${ }^{\dagger}$ Hardy-Weinberg equilibrium in whites $\chi^{2}=0.035, \mathrm{df}=2, p>0.05$ and in blacks $\chi^{2}=0.75, \mathrm{df}=2, p>0.05$. 
Table 2. Associations of the $\alpha 2$-adrenergic receptor gene C-1291G polymorphism with body composition measured in white men and women

\begin{tabular}{|c|c|c|c|c|c|c|c|c|c|c|}
\hline & \multicolumn{5}{|c|}{ Men } & \multicolumn{5}{|c|}{ Women } \\
\hline & $N$ & $\begin{array}{c}\text { Noncarriers } \\
\text { of the G-1291 } \\
\text { allele }\end{array}$ & $N$ & $\begin{array}{c}\text { Carriers } \\
\text { of the G-1291 } \\
\text { allele }\end{array}$ & $p$ & $N$ & $\begin{array}{c}\text { Noncarriers } \\
\text { of the G-1291 } \\
\text { allele }\end{array}$ & $N$ & $\begin{array}{c}\text { Carriers } \\
\text { of the G-1291 } \\
\text { allele }\end{array}$ & $p$ \\
\hline BMI $\left(\mathrm{kg} / \mathrm{m}^{2}\right)$ & 137 & $26.6 \pm 0.4$ & 102 & $26.9 \pm 0.4$ & 0.54 & 123 & $25.0 \pm 0.4$ & 131 & $25.1 \pm 0.4$ & 0.99 \\
\hline FAT (kg) & 127 & $19.5 \pm 0.8$ & 99 & $21.0 \pm 1.0$ & 0.24 & 117 & $20.8 \pm 0.9$ & 127 & $21.5 \pm 0.9$ & 0.60 \\
\hline$\%$ FAT (\%) & 127 & $22.3 \pm 0.6$ & 99 & $23.6 \pm 0.7$ & 0.20 & 117 & $29.9 \pm 0.8$ & 127 & $30.4 \pm 0.7$ & 0.64 \\
\hline TER & 126 & $1.69 \pm 0.04$ & 93 & $1.75 \pm 0.05$ & 0.31 & 113 & $0.92 \pm 0.02$ & 125 & $0.89 \pm 0.02$ & 0.28 \\
\hline SF8 (mm) & 126 & $130 \pm 4$ & 93 & $133 \pm 5$ & 0.63 & 113 & $164 \pm 5$ & 125 & $166 \pm 5$ & 0.82 \\
\hline $\operatorname{AVF}\left(\mathrm{cm}^{2}\right)$ & 127 & $108 \pm 3$ & 98 & $110 \pm 4$ & 0.70 & 115 & $79 \pm 3$ & 125 & $70 \pm 3$ & 0.02 \\
\hline $\operatorname{ASF}\left(\mathrm{cm}^{2}\right)$ & 127 & $225 \pm 3$ & 98 & $226 \pm 4$ & 0.84 & 115 & $289 \pm 5$ & 125 & $282 \pm 5$ & 0.33 \\
\hline $\operatorname{ATF}\left(\mathrm{cm}^{2}\right)$ & 127 & $333 \pm 4$ & 98 & $336 \pm 5$ & 0.66 & 115 & $367 \pm 5$ & 125 & $352 \pm 5$ & 0.03 \\
\hline
\end{tabular}

Data are Least Square Mean \pm SEM (see text for details).

$N$, number of subjects; BMI, body mass index; FAT, fat mass; \%FAT, percentage body fat; TER, trunk-to-extremity skinfold ratio; SF8, sum of eight skinfolds; AVF, abdominal visceral fat area; ASF, subcutaneous fat area; ATF, total fat area.

\section{Discussion}

Previous reports suggest that there is a genetic component in the response of catecholamine-stimulated lipolysis of abdominal subcutaneous fat cells to prolonged overfeeding (27), exercise training (28), or a very-low-calorie diet (29). The adrenergic receptor genes are reasonable candidates to account for these genetic effects. The present study focuses on one such candidate gene, the ADRA2A gene. In the present study, a polymorphism in the promoter region of the ADRA2A gene (C-1291G polymorphism) was investigated for its effect on body fat and fat distribution in black and white subjects. The impact of the ADRA2A polymorphism was marginal in white subjects; the association observed with AVF $(p=0.02)$ and ATF $(p=0.03)$ in women explained

Table 3. Associations of the $\alpha 2$-adrenergic receptor gene C-1291G polymorphism with body composition measured in black men and women

\begin{tabular}{|c|c|c|c|c|c|c|c|c|c|c|}
\hline & \multicolumn{5}{|c|}{ Men } & \multicolumn{5}{|c|}{ Women } \\
\hline & $N$ & $\begin{array}{c}\text { Noncarriers } \\
\text { of the G-1291 } \\
\text { allele }\end{array}$ & $N$ & $\begin{array}{c}\text { Carriers } \\
\text { of the G-1291 } \\
\text { allele }\end{array}$ & $p$ & $N$ & $\begin{array}{c}\text { Noncarriers } \\
\text { of the G-1291 } \\
\text { allele }\end{array}$ & $N$ & $\begin{array}{c}\text { Carriers } \\
\text { of the G-1291 } \\
\text { allele }\end{array}$ & $p$ \\
\hline BMI $\left(\mathrm{kg} / \mathrm{m}^{2}\right)$ & 12 & $26.9 \pm 1.5$ & 77 & $27.3 \pm 0.6$ & 0.81 & 13 & $28.1 \pm 1.7$ & 168 & $28.2 \pm 0.5$ & 0.97 \\
\hline FAT (kg) & 12 & $23.5 \pm 3.2$ & 74 & $20.6 \pm 1.2$ & 0.40 & 12 & $28.0 \pm 3.5$ & 129 & $27.9 \pm 1.1$ & 0.99 \\
\hline$\%$ FAT (\%) & 12 & $26.1 \pm 2.1$ & 74 & $22.9 \pm 0.8$ & 0.17 & 12 & $35.0 \pm 2.4$ & 129 & $36.1 \pm 0.7$ & 0.65 \\
\hline TER & 10 & $1.57 \pm 0.15$ & 68 & $1.91 \pm 0.06$ & 0.04 & 10 & $1.18 \pm 0.08$ & 125 & $1.01 \pm 0.02$ & 0.04 \\
\hline SF8 (mm) & 10 & $126 \pm 18$ & 68 & $121 \pm 7$ & 0.80 & 10 & $178 \pm 18$ & 125 & $179 \pm 5$ & 0.98 \\
\hline $\operatorname{AVF}\left(\mathrm{cm}^{2}\right)$ & 12 & $94 \pm 10$ & 74 & $75 \pm 4$ & 0.08 & 12 & $89 \pm 7$ & 125 & $65 \pm 2$ & 0.002 \\
\hline $\operatorname{ASF}\left(\mathrm{cm}^{2}\right)$ & 12 & $208 \pm 12$ & 74 & $238 \pm 5$ & 0.03 & 12 & $338 \pm 16$ & 125 & $346 \pm 5$ & 0.63 \\
\hline $\operatorname{ATF}\left(\mathrm{cm}^{2}\right)$ & 12 & $302 \pm 16$ & 74 & $313 \pm 6$ & 0.53 & 12 & $427 \pm 17$ & 125 & $412 \pm 5$ & 0.39 \\
\hline
\end{tabular}

Data are Least Square Mean \pm SEM (see text for details).

$N$, number of subjects; BMI, body mass index; FAT, fat mass; \%FAT, percentage body fat; TER, trunk-to-extremity skinfold ratio; SF8, sum of eight skinfolds; AVF, abdominal visceral fat area; ASF, subcutaneous fat area; ATF, total fat area. 
less than $1 \%$ of the variance. In black subjects, the association analyses revealed that the G-1291 allele was associated with a $27 \%$ increase of TER in men (3.8\% of variance accounted for by the polymorphism), whereas in black women it was associated with a $14 \%$ decrease in TER $(2.9 \%$ of variance accounted for by the polymorphism) and a $27 \%$ decrease in AVF (2.5\% of variance accounted for by the polymorphism). The association observed with ASF in black men, although significant $(p=0.03)$, explained only $0.4 \%$ of the variance. Because TER is an indicator of the propensity to store fat in the truncal-abdominal area relative to the extremities, these results suggest that black men who are carriers of the G-1291 allele are more prone to develop an android pattern of fat distribution while their female counterparts are more susceptible to develop a gynoid pattern of fat distribution. This gender difference in fat distribution is supported by the association observed in black women in whom the C-1291G polymorphism of the ADRA2A gene is associated with a reduced amount of abdominal visceral fat after adjustment for total body fatness.

The race differences observed in the impact of the ADRA2A C-1291G polymorphism on the phenotypes investigated are most likely attributable to the difference in the allele frequencies between the two groups. With more than a 2 -fold higher frequency of the G-1291 allele in blacks (0.66) compared to whites $(0.27)$, the impact of the polymorphism is expected to be higher in the black population compared to the white population. It is not rare to encounter such a difference between races for a polymorphism in a given candidate gene. Previous reports have shown such race difference for lipid metabolism candidate gene polymorphisms in other cohorts $(30,31)$. Several evolutionary forces such as mutation, migration, natural selection, or random genetic drift can produce changes in allele frequencies and thus contribute to explaining the difference observed between blacks and whites for the frequency of ADRA2A C-1291G polymorphism.

The results of association analyses in blacks also revealed sex differences in the impact of the polymorphism, which is associated with a tendency to store fat in the trunk for males compared to a tendency to store fat in the extremities for females. A few studies have suggested that the antilypolytic effect of the $\alpha 2$-adrenergic receptor varies between subcutaneous and visceral fat depots according to gender and obesity status. For instance, the $\alpha 2$-adrenergic receptor exhibited a lower antilipolytic sensitivity in abdominal than in gluteal subcutaneous fat of nonobese females, leading to a higher catecholamine-induced lipolysis through the $\beta$ adrenergic receptor component in the former compared to the latter, and this regional difference was more pronounced in women than in men (7). Also, it has been proposed that the number of $\alpha 2$-adrenergic receptors varies between fat depots being lowest in AVF and highest in gluteal fat depots with intermediate values in ASF (4). Furthermore, the maximal antilypolytic response was shown to be more pronounced in abdominal and gluteal subcutaneous fat depots of obese women compared to their nonobese counterparts, suggesting that a strong $\alpha 2$ component could lead to subcutaneous fat accumulation (4). Thus, if we speculate that the G-1291 allele is associated with a higher $\alpha 2$-adrenergic component than the C-1291 allele (change in promoter sequence that leads to a higher ADRA2A gene expression), the effect should be stronger in the gluteal region of women, which has a high $\alpha 2$ adrenergic component, than in the abdominal subcutaneous region. This will lead to a greater fat accumulation in extremities of women as compared to men, which is in agreement with the results observed in the present study. The $\alpha 2$-component of the AVF behaves differently. It has been hypothesized, although direct experimental evidence in support of the hypothesis is lacking, that the increase in fat mobilization from the visceral depot in upperbody obesity results in a higher free fatty acid release draining through the portal vein (32). The blunted metabolism observed in abdominal visceral obesity is characterized by high lipolytic $\beta 3$-adrenergic receptor and low antilypolytic $\alpha 2$ adrenergic receptor sensitivities in men (8).

Considering the evidence showing that it is the balance between the $\alpha 2$ - and the $\beta$-adrenergic receptors that provides the most important physiological information about fat accumulation and distribution, other polymorphisms in the $\beta 2$ - and $\beta 3$-adrenergic receptors are also important to consider because they could have an impact on the $\alpha 2$ - $/ \beta$-adrenergic balance. Several studies reported evidence of association between polymorphisms in the ADRA2A gene $(18,19)$, the ADRB2 gene $(19,33-37)$, the ADRB3 gene $(19,38-40)$, and obesity-related traits. The effects of the ADRA2A polymorphism on TER reported in the present study are in agreement with those previously observed in the Québec Family Study (18) in which women without the $6.3-\mathrm{kb}$ allele of the Dra I polymorphism in the ADRA2A gene were characterized by a low TER (18). There is good evidence showing that the Gln27Glu polymorphism in the $\beta 2$-adrenergic receptor is associated with an increased risk of obesity in men $(33,36)$ and a greater accumulation of fat in women $(33,35)$. Also, the rare allele of the $\beta 3$-adrenergic receptor is more frequent in obese men (38) and is associated with elevated BMI (39) and with visceral obesity in women (40). Results from a recent study on interactions between polymorphisms in adrenergic receptor genes reported an interaction effect between $\alpha 2$ - and $\beta 2$-adrenergic receptor gene polymorphisms on total, high- and low-density lipoprotein cholesterol content, and between $\alpha 2$ - and 
$\beta 3$-adrenergic receptor gene polymorphisms on abdominal fat content (19). These results suggest that, in addition to the main effects of candidate gene polymorphisms taken one at a time, interaction effects are also important in studying the impact of candidate genes on variation in obesity-related traits.

The results reported in this study should be interpreted with caution. First, there is no evidence showing any functional effect of the C1291G polymorphism in the promoter region of the ADRA2 gene. To the best of our knowledge, no study has investigated the impact of this polymorphism on the expression of the ADRA2 gene. However, even if this polymorphism has no effect on the expression of the gene, one must keep in mind that it could be in linkage disequilibrium with another functional polymorphism within the gene and thus explain the association observed. Second, considering the number of tests performed and the borderline $p$ values observed for some of the positive findings, we cannot exclude the possibility that the observed associations are due to chance. Replication of these findings in other populations would be needed to evaluate the real impact of this polymorphism on body fat and fat distribution.

In summary, the results of this study indicate that a polymorphism in the promoter region of the ADRA2A gene is associated with an android pattern of fat distribution in black men and that their female counterparts are more prone to develop a gynoid pattern of fat distribution. The results can be seen as supportive of those previously obtained in the Québec Family Study and suggest that DNA sequence variation in the ADRA2A gene influences the propensity to store fat in the abdominal area independently of total body fatness.

\section{Acknowledgments}

The HERITAGE Family Study is supported by NHLBI through grants HL47323 (A.S.L.), HL47317 (D.C.R.), HL47327 (J.S.S.), HL47321 (J.H.W.), and HL45670 (C.B.). A.S.L. is partially supported by the Henry L. Taylor endowed Professorship in Exercise Science and Health Enhancement. C.B. is partially supported by the George A. Bray chair in nutrition. Thanks are expressed to all the investigators, local project coordinators, research assistants, laboratory technicians, and secretaries who have contributed to this study.

\section{References}

1. Lafontan M, Berlan M. (1993) Fat cell adrenergic receptors and the control of white and brown fat cell function. J. Lipid Res. 34: 1057-1091.

2. Berlan M, Lafontan M. (1985) Evidence that epinephrine acts preferentially as an antilipolytic agent in abdominal human subcutaneous fat cells: Assessment by analysis of beta and alpha 2 adrenoceptor properties. Eur. J. Clin. Invest. 15: 341-348.

3. Mauriège P, Galitzky J, Berlan M, Lafontan M. (1987) Heterogeneous distribution of beta and alpha-2 adrenoceptor binding sites in human fat cells from various fat deposits: Functional consequences. Eur. J. Clin. Invest. 17: 156-165.

4. Lafontan M, Berlan M. (1995) Fat cell alpha 2-adrenoceptors: The regulation of fat cell function and lipolysis. Endocr. Rev. 16: 716-738.

5. Mauriège P, Després JP, Prud'homme D, et al. (1991) Regional variation in adipose tissue lipolysis in lean and obese men. J. Lipid Res. 32: 1625-1633.

6. Mauriège P, Prud'homme D, Lemieux S, Tremblay A, Després JP. (1995) Regional differences in adipose tissue lipolysis from lean and obese women: Existence of postreceptor alterations. Am. J. Physiol. 269: E34l-E350.

7. Wahrenberg H, Lonnqvist F, Arner P. (1989) Mechanisms underlying regional differences in lipolysis in human adipose tissue. J. Clin. Invest. 84: 458-467.

8. Lönnqvist F, Thörne A, Large V, Arner P. (1997) Sex differences in visceral fat lipolysis and metabolic complications of obesity. Arterioscler. Thromb. Vasc. Biol. 17: 1472-1480.

9. Van Harmelen V, Lönnqvist F, Thörne A, et al. (1997) Noradrenaline-induced lipolysis in isolated mesenteric, omental and subcutaneous adipocytes from obese subjects. Int. J. Obes. Relat. Metab. Disord. 21: 972-979.

10. Stich V, de Glisezinski I, Crampes F, et al. (1999) Activation of antilipolytic alpha(2)-adrenergic receptors by epinephrine during exercise in human adipose tissue. Am. J. Physiol. 277: R1076-R1083.

11. Stich V, De Glisezinski I, Crampes F, et al. (2000) Activation of alpha(2)-adrenergic receptors impairs exercise-induced lipolysis in SCAT of obese subjects. Am. J. Physiol. Regul. Integr. Comp. Physiol. 279: R499-R504.

12. Pérusse L, Rice T, Province MA, et al. (2000) Familial aggregation of amount and distribution of subcutaneous fat and their responses to exercise training in the HERITAGE family study. Obes. Res. 8: 140-150.

13. Rice T, Daw EW, Gagnon J, et al. (1997) Familial resemblance for body composition measures: The HERITAGE Family Study. Obes. Res. 5: 557-562.

14. Rice T, Després JP, Daw EW, et al. (1997) Familial resemblance for abdominal visceral fat: The HERITAGE family study. Int. J. Obes. Relat. Metab. Disord. 21 : 1024-1031.

15. Castan I, Devedjian JC, Valet P, Paris H, Lafontan M. (1995) Human adipocytes express alpha 2-adrenergic receptor of the alpha 2A- subtype only: Pharmacological and genetic evidence. Fundam. Clin. Pharmacol. 9: 569-575.

16. Hoehe MR, Berrettini WH, Lentes KU. (1988) Dra I identifies a two allele DNA polymorphism in the human alpha 2-adrenergic receptor gene (ADRAR), using a $5.5 \mathrm{~kb}$ probe (p ADRAR). Nucleic Acids Res. 16: 9070.

17. Morris BJ, Zee RY, Ying LH, Griffiths LR. (1993) Independent, marked associations of alleles of the insulin receptor and dipeptidyl carboxypeptidase-I genes with essential hypertension. Clin. Sci. (Colch) 85: 189-195.

18. Oppert JM, Tourville J, Chagnon M, et al. (1995) DNA polymorphisms in the apha 2-and beta 2-adrenoceptor genes and regional fat distribution in humans: Association and linkage studies. Obes. Res. 3: 249-255.

19. Ukkola O, Rankinen T, Weisnagel SJ, et al. (2000) Interactions among the alpha2-, beta2-, and beta3-adrenergic receptor genes and obesity-related phenotypes in the Quebec Family Study. Metabolism 49: 1063-1070.

20. Lario S, Calls J, Cases A, Oriola J, Torras A, Rivera F. (1997) MspI identifies a biallelic polymorphism in the promoter region of the alpha2A-adrenergic receptor gene. Clin. Genet. 51: 129-130.

21. Bouchard C, Leon AS, Rao DC, Skinner JS, Wilmore JH, Gagnon J. (1995) The HERITAGE family study. Aims, design, and measurement protocol. Med. Sci. Sports Exerc. 27: 721-729.

22. Wilmore JH, Stanforth PR, Domenick MA, et al. (1997) Reproducibility of anthropometric and body composition measurements: The HERITAGE Family Study. Int. J. Obes. Relat. Metab. Disord. 21: 297-303.

23. Sambrook J, Fritsch EF, Maniatis T. (1989) Molecular Cloning. Cold Spring Harbor, NY: Cold Spring Harbor Laboratory ed. 
24. SAS Statistical Analysis System. (1996) Cary, North Carolina: SAS Institute Inc.

25. Ott J. (1991) Analysis of Human Genetic Linkage. Baltimore: The John Hopkins University Press.

26. Després JP, Couillard C, Gagnon J, et al. (2000) Race, visceral adipose tissue, plasma lipids, and lipoprotein lipase activity in men and women: The Health, Risk Factors, Exercise Training, and Genetics (HERITAGE) family study. Arterioscler. Thromb. Vasc. Biol. 20: 1932-1938.

27. Mauriège P, Després JP, Marcotte M, et al. (1992) Adipose tissue lipolysis after long-term overfeeding in identical twins. Int. J. Obes. Relat. Metab. Disord. 16: 219-225.

28. Tremblay A, Poehlman ET, Després JP, Thériault G, Danforth E, Bouchard C. (1997) Endurance training with constant energy intake in identical twins: Changes over time in energy expenditure and related hormones. Metabolism 46: 499-503.

29. Stich V, Harant I, De Glisezinski I, et al. (1997) Adipose tissue lipolysis and hormone-sensitive lipase expression during very-low-calorie diet in obese female identical twins. J. Clin. Endocrinol. Metab. 82: 739-744.

30. Harris MR, Bunker CH, Hamman RF, Sanghera DK, Aston CE, Kamboh MI. (1998) Racial differences in the distribution of a low density lipoprotein receptor-related protein (LRP) polymorphism and its association with serum lipoprotein, lipid and apolipoprotein levels. Atherosclerosis 137: 187-195.

31. Gerdes LU, Klausen IC, Sihm I, Faergeman O. (1992) Apolipoprotein E polymorphism in a Danish population compared to findings in 45 other study populations around the world. Genet. Epidemiol. 9: 155-167.

32. Björntorp P. (1990) "Portal" adipose tissue as a generator of risk factors for cardiovascular disease and diabetes. Arteriosclerosis 10: 493-496.
33. Hellström L, Large V, Reynisdottir S, Wahrenberg H, Arner P. (1999) The different effects of a Gln27Glu beta 2-adrenoceptor gene polymorphism on obesity in males and in females. J. Intern. Med. 245: 253-259.

34. Ishiyama-Shigemoto S, Yamada K, Yuan X, Ichikawa F, Nonaka K. (1999) Association of polymorphisms in the beta2adrenergic receptor gene with obesity, hypertriglyceridaemia, and diabetes mellitus. Diabetologia 42: 98-101.

35. Large V, Hellström L, Reynisdottir S, et al. (1997) Human beta-2 adrenoceptor gene polymorphisms are highly frequent in obesity and associate with altered adipocyte beta-2 adrenoceptor function. J. Clin. Invest. 100: 3005-3013.

36. Meirhaeghe A, Helbecque N, Cottel D, Amouyel P. (2000) Impact of polymorphisms of the human beta2-adrenoceptor gene on obesity in a French population. Int. J. Obes. Relat. Metab. Disord. 24: 382-387.

37. Mori Y, Kim-Motoyama H, Ito Y, et al. (1999) The Gln27Glu beta2-adrenergic receptor variant is associated with obesity due to subcutaneous fat accumulation in Japanese men Biochem. Biophys. Res. Commun. 258: 138-140.

38. Kim-Motoyama H, Yasuda K, Yamaguchi T, et al. (1997) A mutation of the beta 3-adrenergic receptor is associated with visceral obesity but decreased serum triglyceride. Diabetologia 40: 469-472.

39. McFarlane-Anderson N, Bennett F, Wilks R, et al. (1998) The Trp64Arg mutation of the beta3-adrenergic receptor is associated with hyperglycemia and current body mass index in Jamaican women. Metabolism 47: 617-621.

40. Sakane N, Yoshida T, Umekawa T, Kondo M, Sakai Y, Takahashi T. (1997) Beta 3-adrenergic-receptor polymorphism: A genetic marker for visceral fat obesity and the insulin resistance syndrome. Diabetologia 40: 200-204. 